\title{
Antimicrobial activity and partial characterization of bacteriocin- like inhibitory substances produced by Lactobacillus spp. isolated from artisanal Mexican cheese
}

\author{
Priscilia Y. Heredia-Castro, ${ }^{*}$ José I. Méndez-Romero, ${ }^{*}$ Adrián Hernández-Mendoza, ${ }^{*}$ Evelia Acedo-Félix, $†$ \\ Aarón F. González-Córdova, ${ }^{*}$ and Belinda Vallejo-Cordoba* ${ }^{* 1}$ \\ *Laboratorio de Química y Biotecnología de Productos Lácteos, Coordinación de Tecnología de Alimentos de Origen Animal (CTAOA), and \\ †Laboratorio de Microbiología Molecular, Coordinación de Ciencia de los Alimentos (CA), Centro de Investigación en Alimentación y Desarrollo, \\ A.C. (CIAD, A.C.) Carretera a La Victoria Km 0.6, Apartado Postal 1735 Hermosillo, Sonora, 83304, México
}

\begin{abstract}
Lactobacillus spp. from Mexican Cocido cheese were shown to produce bacteriocin-like substances (BLS) active against Staphylococcus aureus, Listeria innocua, Escherichia coli, and Salmonella typhimurium by using the disk diffusion method. Crude extracts of Lactobacillus fermentum showed strong inhibitory activity against Staph. aureus, L. innocua, E. coli, and Salmonella cholerae. Complete inactivation of antimicrobial activity was observed after treatment of crude extracts with proteinase $\mathrm{K}$, pronase, papain, trypsin, and lysozyme, confirming their proteinaceous nature. However, antimicrobial activity was partly lost for some of the crude extracts when treated with $\alpha$-amylase, indicating that carbohydrate moieties were involved. The antimicrobial activity of the crude extracts was stable at $65^{\circ} \mathrm{C}$ for 30 min over a wide $\mathrm{pH}$ range (2-8), and addition of potassium chloride, sodium citrate, ethanol, and butanol did not affect antibacterial activity. However, antimicrobial activity was lost after heating at $121^{\circ} \mathrm{C}$ for $15 \mathrm{~min}$, addition of methanol or Tween 80. Fourteen out of 18 Lactobacillus spp. showed antimicrobial activity against different test microorganisms, and 12 presented bacteriocin-like substances. Generation time and growth rate parameters indicated that the antimicrobial activity of crude extracts from 3 different strains was effective against the 4 indicator microorganisms. One of the crude extracts showed inhibition not only against gram-positive but also against gram-negative bacteria. Bacteriocin-like substances produced by this specific Lactobacillus strain showed potential for application as a food biopreservative.
\end{abstract}

Received July 11, 2015.

Accepted September 2, 2015.

${ }^{1}$ Corresponding author: vallejo@ciad.mx
Key words: bacteriocin, lactic acid bacteria, antimicrobial activity

\section{INTRODUCTION}

Lactic acid bacteria (LAB) have been used in different foods for the production of organic substances that contribute to the sensory attributes and the preservation of food (Parada et al., 2007). The preservative properties are based on the antimicrobial metabolites such as organic acids, hydrogen peroxide, diacetyl, reuterin, antifungal peptides, and bacteriocins (Ponce et al., 2008; Arqués et al., 2011; Stoyanova et al., 2012; Ghanbari et al., 2013). Bacteriocins are ribosomally synthesized peptides with antimicrobial activity produced by bacteria such as LAB (Lactococcus, Lactobacillus, Pediococcus, Streptococcus, Enterococcus, and Leuconostoc) that are of particular interest due to their potential use as biopreservatives in the food industry (Todorov et al., 2011; Balciunas et al., 2013). The interest in the application of bacteriocins in food preservation has increased in the last years due their nontoxicity, sensitivity to proteases, general $\mathrm{pH}$ and heat stability, and antimicrobial effect against species of gram-positive bacteria, such as Staphylococcus aureus, Clostridium tyrobutyricum, Listeria innocua, Listeria monocytogenes, and Bacillus cereus. Additionally, a few bacteriocins have activity against gram-negative bacteria such as Escherichia coli, Salmonella typhimurium, Helicobacter pylori NCIPD 230, and Campylobacter jejuni (Gálvez et al., 2007; García et al., 2010; Todorov et al., 2010; Reis et al., 2012). However, only nisin (Lactococcus lactis) and pedocin PA-1 (Pediococcus acidilactici) are approved and permitted for preservation of foods (Parada et al., 2007; Pinto et al., 2011; Biscola et al., 2013). The factors affecting the bacteriocin activity in different food systems are the composition (proteins and lipids), enzymatic degradation, manufacturing process (high temperatures), physical properties, such as $\mathrm{pH}$ and 
additives present (Gálvez et al., 2007; Parada et al., 2007; Hartmann et al., 2011; Gao et al., 2013). Thus, the successes of using bacteriocins in the food industry for the control of different pathogens are necessary to demonstrate the antimicrobial activity of bacteriocins by in vitro studies and in food systems (Gálvez et al., 2008; Biscola et al., 2013). In dairy products, the antimicrobial effect of different bacteriocins against grampositive bacteria has been studied, but few reports are available on the effect against gram-negative bacteria. Thus, demand for natural antimicrobial compounds has brought interest in new bacteriocins able to enhance dairy safety.

The aim of the present work was to screen for BLS production in wild Lactobacillus, isolated during the manufacture of artisanal Mexican Cocido cheese, with bioactivity against gram-positive and gram-negative bacteria. Mexican Cocido cheese is a semi-soft pasta filata cheese variety typical of the northwest of Mexico. It is made from raw milk using traditional techniques, which include acidification by using cheese whey from a previous cheese batch and renneting. A typical stage of the manufacturing is the process of cooking the curd until it reaches a dough-like consistency. Then it is placed into molds where it is shaped and cooled.

\section{MATERIALS AND METHODS}

\section{Strains, Media, and Culture Conditions}

All 18 wild Lactobacillus strains were obtained from the culture collection of the Dairy Laboratory at the Food Research and Development Center, A.C. (CIAD, A.C., Hermosillo, Sonora, Mexico). These strains were isolated during the making of artisanal Mexican Cocido cheese in Hermosillo, Sonora, Mexico. Briefly, at least 4 colonies were randomly picked from de Man, Rogosa, and Sharpe (MRS; BD Difco, Sparks, MD) agar count plates from different samples collected from cheese milk, whey, curd, and cheese. After purification, colonies were stored at $-80^{\circ} \mathrm{C}$ in in $(80 \%, \mathrm{vol} / \mathrm{vol})$ glycerol until further characterization (González et al., 2007).

Prior to each experiment, Lactobacillus strains were subcultured in $10 \mathrm{~mL}$ of MRS at $37^{\circ} \mathrm{C}(\mathrm{pH}$ 6.5). Three consecutive cultures (1\% inoculum) were prepared and incubated for 24,20 , and $16 \mathrm{~h}$, respectively. The last culture was used as the inoculum for all the experiments (fresh culture).

Staphylococcus aureus ATCC 29213, L. innocua ATCC 33090, S. typhimurium ATCC 14028, and E. coli ATCC 25922 were cultured in brain heart infusion broth (BHI; BD Difco, Sparks, MD). Three subcultures were inoculated at $1 \%$ and incubated at $37^{\circ} \mathrm{C}$.
The first subculture was incubated for 24 and $16 \mathrm{~h}$, and the last subculture was incubated for $8 \mathrm{~h}$.

\section{Molecular Identification of $L A B$}

Lactic acid bacteria were grown in MRS broth for 18 h. Subsequently, $1 \mathrm{~mL}$ of sample was taken for DNA extraction using the commercial protocol PrepMan Ultra Sample Preparation Reagent (Applied Biosystems, Foster City, CA). The method of amplification was based in the protocol of MicroSEQ Identification Systems (Applied Biosystems). The PCR cycles were carried out in a thermocycler endpoint (Eppendorf, Hamburg, Germany). Each PCR product was purified with ExoSAP-IT (Affymetrix, Santa Clara, CA) and then sequenced based on the MicroSeq protocol. Sequencing reactions were purified using the BigDye Xterminator protocol (Applied Biosystems). The purified samples were examined in a 3500 Genetic Analyzer (Applied Biosystems). The sequences obtained were analyzed in the MicroSeq software v2.0 (Applied Biosystems), and compared with the library of MicroSeq Bacterial 500 (Applied Biosystems) to determine the identity of the strains by their similarity to reference strains.

\section{Preparation of CE}

Lactobacillus strains were grown in MRS broth and incubated for $16,18,24$, and $72 \mathrm{~h}$ at $37^{\circ} \mathrm{C}$ in water bath shaker (Lab-Line Instruments Inc., Melrose Park, IL). Aliquots of culture medium were centrifuged at $4,000 \times g$ for $20 \mathrm{~min}$, at $4^{\circ} \mathrm{C}$. The crude extracts $(\mathbf{C E})$ were adjusted to $\mathrm{pH} 6.5$ with a $1 \mathrm{~N} \mathrm{NaOH}$, treated with catalase enzyme $(1,000 \mathrm{U} / \mathrm{mL})$ for $1 \mathrm{~h}$ at $25^{\circ} \mathrm{C}$, and filter sterilized $(0.22 \mu \mathrm{m}$, Millex-GV, Millipore $\mathrm{SpA}$, Milan, Italy). The untreated and treated CE were stored at $4^{\circ} \mathrm{C}$ (Karapetyan et al., 2010).

\section{Antimicrobial Activity Determination}

Antibacterial activity was tested against Staph. aureus ATCC 29213, L. innocua ATCC 33090, S. typhimurium ATCC 14028, and E. coli ATCC 25922 by the disk diffusion method. The filter-sterilized $\mathrm{CE}$ were used to evaluate antimicrobial activity. An aliquot of $20 \mu \mathrm{L}$ supernatant was applied on a sterilized cellulose disk $(6 \mathrm{~mm})$ placed on a BHI soft agar plate $(0.8 \%$ wt/vol $)$ inoculated with each pathogen $\left(10^{7} \mathrm{cfu} / \mathrm{mL}\right)$. Plates were incubated at $37^{\circ} \mathrm{C}$ for $24 \mathrm{~h}$, and the diameters of the inhibition zones around the disk were measured (Nespolo and Brandelli, 2010). The CE with inhibition zones larger or equal to $6 \mathrm{~mm}$ were selected (Ponce et al., 2008). 


\section{Effect of Enzymes on Antimicrobial Activity of CE}

The $\mathrm{CE}$ were evaluated to find out if the inhibition was due to bacteriocin-like inhibitory substances (BLS). Thus, CE were treated with papain $(30 \mathrm{U} / \mathrm{mg})$, proteinase $\mathrm{K}(30 \mathrm{U} / \mathrm{mg})$, pronase $\mathrm{E}(3.5 \mathrm{U} / \mathrm{mg})$, lysozyme $(35,000 \mathrm{U} / \mathrm{mg}), \alpha$-amylase $(30 \mathrm{U} / \mathrm{mg})$, and pepsin (250 U/mg) (all from Sigma-Aldrich, St. Louis, MO) at a concentration of $1 \mathrm{mg} / \mathrm{mL}$. Enzymes were dissolved $(0.2 \%$, wt $/ \mathrm{vol})$ in $0.05 \mathrm{~mol} / \mathrm{L}$ Tris, $5 \mathrm{mmol} / \mathrm{L} \mathrm{CaCl}_{2}$ buffer ( $\mathrm{pH} 7$ ). For pepsin testing, the enzyme was dissolved in citrate buffer ( $\mathrm{pH} 3)$. Enzyme solutions were filter sterilized $(0.22 \mu \mathrm{m}$, Millex-GV, Millipore SpA). The $\mathrm{CE}$ were incubated with the different enzyme solutions at $37^{\circ} \mathrm{C}$ for $2 \mathrm{~h}$, after which the retention of BLS in treated samples was determined by the disk diffusion method previously described (Todorov and Dicks, 2006).

\section{Effect of $\mathrm{pH}$, Temperature, Organic Solvents, and Additives on Antimicrobial Substances}

The effect of $\mathrm{pH}$ on the antimicrobial substance was tested by adjusting the $\mathrm{pH}$ of the $\mathrm{CE}$ to values ranging from 2 to 8 (at increments of $1 \mathrm{pH}$ unit) with sterile $1 \mathrm{~N}$ $\mathrm{NaOH}$ or $1 \mathrm{~N} \mathrm{HCl}$. Incubation was for $30 \mathrm{~min}$ at $30^{\circ} \mathrm{C}$. The samples were tested for antimicrobial activity by using the disk diffusion method. The effect of temperature on the activity of antimicrobial substances was tested by heating the cell CE at $65,75,100$, or $121^{\circ} \mathrm{C}$. Residual antimicrobial activity was tested by the well diffusion method after subjecting the $\mathrm{CE}$ to the different temperatures for $30 \mathrm{~min}$. The effect of organic solvents and additives on the activity of antimicrobial substances was tested by adding 10\% (vol/vol, final concentration) butanol, methanol, and ethanol to CE and $1 \%$ (wt/vol, final concentration) potassium chloride, sodium citrate, or Tween 80 to $\mathrm{CE}$. Antimicrobial activity of $\mathrm{CE}$ treated with additives was evaluated by using disk diffusion method at $37^{\circ} \mathrm{C}$ for $5 \mathrm{~h}$. Untreated CE served as controls (Biscola et al., 2013; Ghanbari et al., 2013).

\section{Growth of Indicator Microorganisms in the Presence of Different CE}

A $20-\mu \mathrm{L}$ aliquot of $\mathrm{CE}$ filter sterilized supernatant (pH 6.5) was added to $150 \mathrm{~mL}$ of BHI culture containing different pathogens, namely, Staph. aureus, E. coli, S. typhimurium, and L. innocua. Then, mixtures were incubated for $24 \mathrm{~h}$. Optical density readings at $600 \mathrm{~nm}$ were recorded every $2 \mathrm{~h}$. Growth data were adjusted with the modified Gompertz equation (Chowdhury et al., 2007):

$$
\log \mathrm{n}=\mathrm{A} \times \operatorname{EXP}\{-\operatorname{EXP}[-\mathrm{B} \times(t)]\} .
$$

This equation was applied to growth on indicator microorganisms with different CE. Log $\mathrm{n}=$ decimal logarithm of microbial counts $[\log (\mathrm{abs})]$ at time $t, \mathrm{~A}$ $=$ average of the logarithmic increase $[\log (\mathrm{abs})], \mathrm{B}=$ relative growth rate at time $\left(\mathrm{h}^{-1}\right)$, and $t=$ time $(\mathrm{h})$.

\section{Statistical Analysis}

The experiments followed a complete randomized design with 3 replicates per treatment: antimicrobial activity at 24,48 , and $72 \mathrm{~h}, \mathrm{CE}$ with enzymes, $\mathrm{pH}$, temperature, organic solvents, and additives. Growth experiments were carried out in duplicate. Data were analyzed by one-way ANOVA with a significance level of $0.5 \%$. Means were analyzed by the comparison test of Tukey-Kramer with a significance level of $0.05 \%$. For statistical analyses, the NCSS statistical software version 2007 (NCSS LLC, Kaysville, UT) was used.

\section{RESULTS AND DISCUSSION}

\section{Molecular Identification}

Lactobacillus strains were identified molecularly by comparing the nucleotide sequences of the $16 \mathrm{Sr}$ gene (500 bases) with other sequences deposited in the database of MicroSEQ bacteria. The MicroSEQ protocol states that a $97 \%$ homology with ATCC strains is enough to determine the molecular identification of bacteria. Thus, most strains were identified as Lactobacillus fermentum with $>99 \%$ homology with $L b$. fermentum ATCC 14931. Only J25 and J33 were identified as Lactobacillus plantarum and Lactobacillus paracasei tolerans with $>99 \%$ homology to ATCC 14917 and ATCC 25599, respectively, and strains J26, J27, J31, J34, J36, and J37 were identified as Lactobacillus pentosus with $>99 \%$ homology to ATCC 8041 (Table 1).

\section{Antimicrobial Activity of CE from Lactobacillus spp. Against Staph. aureus, E. coli, S. typhimurium, and $L$. innocua}

Antimicrobial activity by LAB may be due to different metabolites such as organic acids and hydrogen peroxide and could be erroneously attributed to the production of bacteriocin-like compounds. In this study, the CE were adjusted to $\mathrm{pH} 6.5$ and treated with catalase to eliminate the effect of acid or hydrogen peroxide. Thus, the inhibitory activity of the CE was not due to the production of these compounds. The $\mathrm{CE}$ obtained from Lactobacillus spp. at 16 and $18 \mathrm{~h}$ did not show antimicrobial activity by the disk diffusion 
Table 1. Molecular identification of lactic acid bacteria $(\mathrm{LAB})^{1}$

\begin{tabular}{llc}
\hline Strain & Identified LAB & \% Similarity \\
\hline J10 & Lactobacillus fermentum & 99.72 (ATCC 14931) \\
J20 & Lactobacillus fermentum & 99.78 \\
J23 & Lactobacillus fermentum & 99.78 \\
J24 & Lactobacillus pentosus & 100 (ATCC 8041) \\
J25 & Lactobacillus plantarum & 100 \\
J26 & Lactobacillus pentosus & 100 \\
J27 & Lactobacillus pentosus & 100 \\
J28 & Lactobacillus fermentum & 99.64 \\
J29 & Lactobacillus fermentum & 99.77 \\
J30 & Lactobacillus fermentum & 99.62 \\
J31 & Lactobacillus pentosus & 100 \\
J32 & Lactobacillus fermentum & 99.81 \\
J33 & Lactobacillus paracasei tolerans & 99.99 (ATCC 25599) \\
J34 & Lactobacillus pentosus & 100 \\
J35 & Lactobacillus fermentum & 99.78 \\
J36 & Lactobacillus pentosus & 100 \\
J37 & Lactobacillus pentosus & 99.99 \\
J38 & Lactobacillus fermentum & 99.68 \\
\hline
\end{tabular}

${ }^{1}$ Results are based on $16 \mathrm{Sr}$ gene (500 bases) deposited in the database of MicroSEQ.

method. Nevertheless, most of the CE obtained at 24, 48, and $72 \mathrm{~h}$ presented antimicrobial activity against Staph. aureus, E. coli, S. typhimurium, and L. innocua, except for extracts produced by $L b$. pentosus strain J24, J26, J27, and J34 (Figure 1). However, CE obtained at $72 \mathrm{~h}$ showed the largest antimicrobial activity for each strain $(P<0.05)$; therefore, this time was used for the rest of experiments. The largest antimicrobial activity of bacteriocins at $72 \mathrm{~h}$ as shown in this study is in agreement with previous studies (McClerren et al., 2006; Basurto-Cadena et al., 2012). In fact, authors reported minimum antimicrobial activity at $24 \mathrm{~h}$ and maximum antimicrobial activity after $60 \mathrm{~h}$ for a Bacillus subtilis strain (Basurto-Cadena et al., 2012), suggesting that the antagonistic activity of proteases was lost in the first $24 \mathrm{~h}$, not affecting the activity of the bacteriocins in the rest of the time. Also, McClerren et al. (2006) reported that Bacillus halodurans produced the bacteriocin haloduracin after $90 \mathrm{~h}$ of incubation. It has been reported that several mechanisms may be responsible for the decrease of bacteriocin activity of which protein aggregation, proteolytic degradation (proteases), and bacteriocin adsorption to the cells were reported (De Vuyst et al., 1996).

Among the 14 strains that presented antimicrobial activity against indicator microorganisms, Lb. fermentum strain J23 presented the highest antimicrobial activity against all tested microorganisms. On the other hand, Lb. fermentum strains J20, J28, and J32 presented the highest antimicrobial activity against $E$. coli and S. typhimurium. Simova et al. (2009) reported that $\mathrm{CE}$ of Lactobacillus rhamnosus obtained at $20 \mathrm{~h}$ presented antimicrobial activity against L. innocua, Staph. aureus, and E. coli, whereas Lactobacillus bulgaricus presented activity against Staph. aureus, E. coli, and $S$. typhimurium. However, the antimicrobial activity reported by these authors was lower than the antimicrobial activity found in the present study. The effect of the CE against different test pathogens is very important, particularly against Staph. aureus and E. coli, because these pathogens have been previously found in Fresco cheese manufactured with raw milk (TorresLlanez et al., 2006). Staphylococcus aureus has been described as a common contaminant of dairy products and was detected in milk and artisanal Mexican cheeses (Torres-Llanez et al., 2006).

\section{Effect of Enzymes on Antimicrobial Substances Against Staph. aureus, E. coli, S. typhimurium, and $L$. innocua}

The CE from Lactobacillus spp. were treated with different enzymes to verify the proteinaceous nature of the inhibitory substances (Table 2). Determination of the proteinaceous nature of the inhibitory substances confirmed that the antimicrobial agents produced by Lactobacillus spp. were bacteriocin-like substances (BLS), except for those from $L b$. fermentum strains J29 and J30. According to Ghanbari et al. (2013), the inactivation of antimicrobial activity by the action of proteolytic enzymes was an indication of the proteinaceous nature of BLS.

Additionally, BLS from $L b$. fermentum strains J10, $\mathrm{J} 20, \mathrm{~J} 25, \mathrm{~J} 28$, and J32 and $L b$. pentosus strain J36 were inhibited by $\alpha$-amylase, indicating that the bacteriocins produced by Lactobacillus may be glycoproteins (carbohydrate moiety), which require both the glyco and the protein portion of the molecule for the activity. 
This indicates that probably these bacteriocins belong to group IV in their classification, which contains carbohydrates and lipids in the molecular structure (Todorov et al., 2011). However, this fact needs to be confirmed after bacteriocin purification and structure determination. Several glycoprotein bacteriocins have been reported such as Enterococcus faecium DB1 and Lactobacillus brevis DF01, which produced bacteriocins sensitive to $\alpha$-amylase (Seo et al., 2014). Other bacteriocins reported were leuconocin S produced by Leuconostoc paramesenteroides and carnocin 54 produced by Leuconostoc carnosum (Todorov et al., 2010).

\section{Effect of Temperature, $\mathrm{pH}$, Organic Solvents, and Additives on Antimicrobial Substances Against Staph. aureus, E. coli, S. typhimurium, and $L$. innocua}

Temperature Effect. The effect of temperature on the antimicrobial activity of CE against Staph. aureus, E. coli, S. typhimurium, and L. innocua is shown in Table 3 . In general, the antimicrobial activity was stable at $65^{\circ} \mathrm{C}$ for $30 \mathrm{~min}$ and was most unstable at $121^{\circ} \mathrm{C}$ for 15 min. The CE from J20, J23, J25, J28, J32, J37, and J38 showed the most stability to heat treatment, retaining $100 \%$ of antimicrobial activity after $30 \mathrm{~min}$ at 65 or $75^{\circ} \mathrm{C}$. However, antimicrobial activity decreased to some extent at $100^{\circ} \mathrm{C}$ for $30 \mathrm{~min}$ because the residual activity of the $\mathrm{CE}$ was around 80 to $90 \%$ (Table 3).
This observation indicates that these bacteriocins may be used as biopreservatives in foods that are subjected to pasteurization, as is the case for dairy foods. Similar results were reported for Pringsulaka et al. (2012), bacteriocins produced by Weissella cibaria N23 were stable after subjecting them to 60 to $100^{\circ} \mathrm{C}$ for $20 \mathrm{~min}$. These bacteriocins retained $50 \%$ of the antimicrobial activity at $100^{\circ} \mathrm{C}$ for $30 \mathrm{~min}$. Conversely, bacteriocins produced by Lb. bulgaricus BB18 and Lb. lactis BCM5 showed high stability to heat treatment, retaining the antimicrobial activity after $60 \mathrm{~min}$ at $100^{\circ} \mathrm{C}$ (Simova et al., 2009). It has been reported that bacteriocin stability to heat treatment produced by different strains may be attributed to differences in ecological and environmental adaptation (Ponce et al., 2008).

$\boldsymbol{p H}$ Effect. The CE produced by Lactobacillus spp. were inhibitory against Staph. aureus, E. coli, S. typhimurium, and $L$. innocua at a wide $\mathrm{pH}$ range (2.0-8.0; Table 3). Similar results were reported where antibacterial activity of different LAB strains presented a wide pH range (4.0-8.0) (Mezaini et al., 2009). Bacteriocin ALP57 from Pediococcus pentosaceus and bacteriocin ALP7 from E. faecium maintained antimicrobial activity against different strains at $\mathrm{pH}$ range from 2 to 8 , but lost activity at pH 12 (Pinto et al., 2009). This is in agreement with the fact that the highest antimicrobial activity was found at the acid or neutral $\mathrm{pH}$ (Ponce et al., 2008). Bacteriocin stability in a wide $\mathrm{pH}$ range, as was shown in this study, is of technological importance
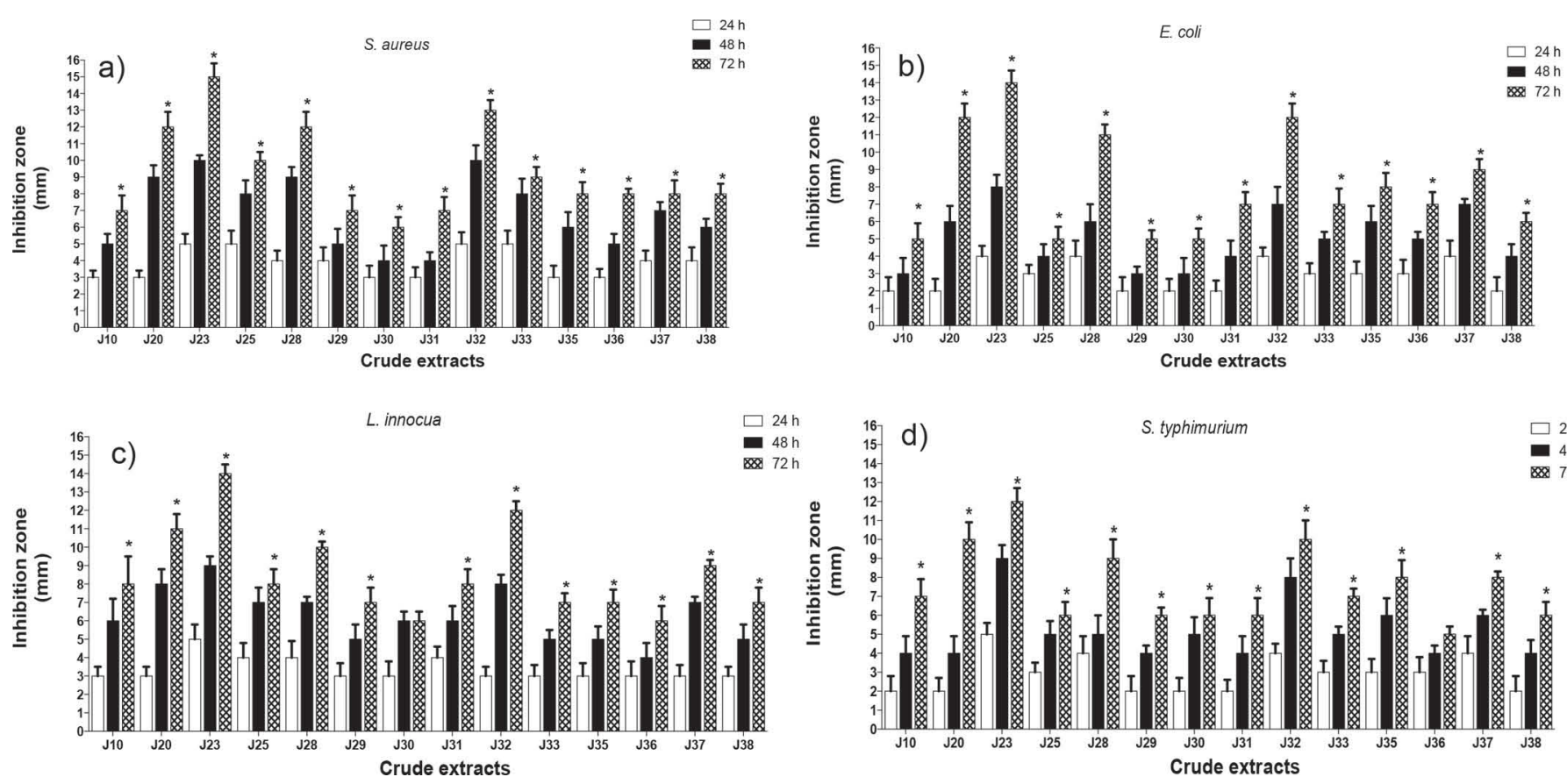

Figure 1. Antimicrobial activity of crude extracts obtained from different Lactobacillus against indicator strains. *Indicates significant differences between 24,48 , and $72 \mathrm{~h}$ for each strain $(P<0.05)$. Error bars indicate $95 \%$ confidence interval. 


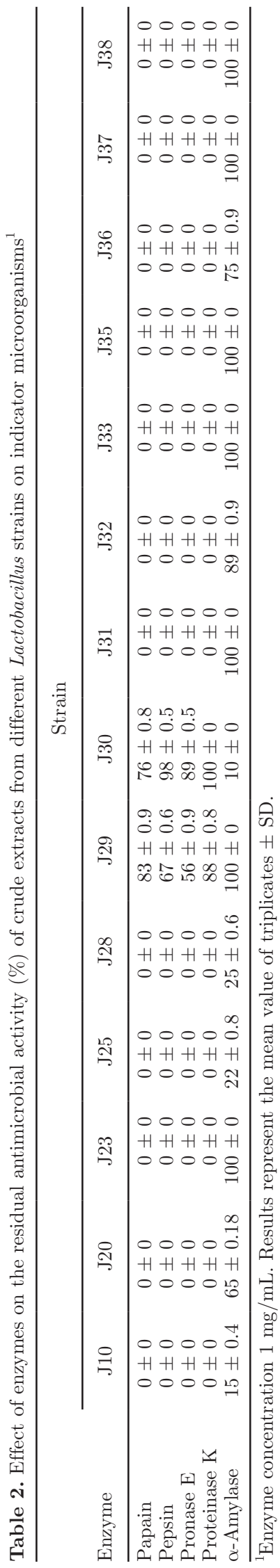

Journal of Dairy Science Vol. 98 No. 12, 2015

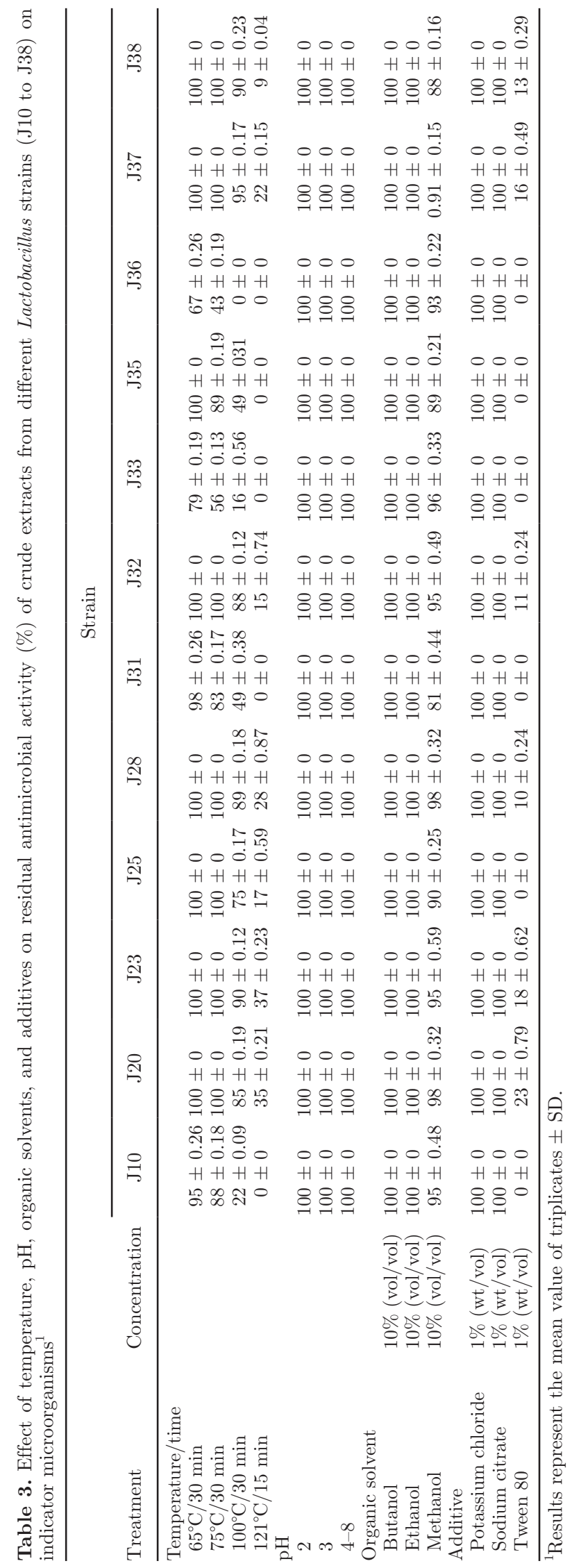


for the dairy industry, because they may be used in different foods, such as fermented milk products.

Organic Solvent and Additive Effects. The CE remained inhibitory to Staph. aureus, E. coli, S. typhimurium, and L. innocua after 30 min of treatment with substances such as sodium citrate and potassium chloride (Table 3). Parada et al. (2007) reported that the bacteriocin lactocin 705 against L. monocytogenes lost activity in the presence of sodium chloride, sodium citrate, ascorbic acid, and sodium lactate. Although the addition of anionic compounds did not affect antibacterial activity against test microorganisms, the addition of Tween 80 decreased their activity (Table 3). Additionally, CE produced by Lactobacillus spp. presented antimicrobial activity against Staph. aureus, E. coli, S. typhimurium, and L. innocua in the presence of different organic solvents (Table 3). Similarly, lactocin RN78 and plantaricin LC74 bacteriocins produced by Lactobacillus spp. maintained antimicrobial activity after treatments with organic solvents such as butanol, ethanol, and methanol. The fact that bacteriocins were stable with organic solvents indicated that they were soluble in them (Ghanbari et al., 2013).

\section{Growth Inhibition of Staph. aureus, E. coli, S. typhimurium, and $L$. innocua in the Presence of Different CE}

Microbial growth parameters growth rate $(\boldsymbol{\mu})$ and generation time $(\mathrm{gt})$ showing inhibition of indicator microorganisms by the different CE containing BLS are summarized in Tables 4, 5, 6, and 7. Coefficients of determination $\left(\mathrm{R}^{2}=0.95\right.$ to 0.99$)$ indicated that the Gompertz model was able to describe microbial growth accurately $(P<0.05)$. Of the $12 \mathrm{CE}$ that presented antimicrobial activity and contained BLS, Lb. fermentum strain J23 showed the longest gt and the lowest $\mu$ compared with the controls (Tables 4, 5, 6 and 7). Thus, the CE from J23 had the greatest inhibitory activity against the 4 test microorganisms and may be the one with the largest concentration of BLS. The CE from J20 and J32 showed the next longest gt and the next lowest $\mu$ compared with the controls, for Staph. aureus and Salmonella, respectively (Tables 5 and 7 ). Therefore, CE from Lb. fermentum strains J20 and J32 had the greatest inhibitory activity against these pathogens after $L b$. fermentum strain J23. Growth inhibition of the indicator microorganism by these $3 \mathrm{CE}$ is shown in Figure 2. It is important to note that CE from J23 inhibited growth of not only gram-positive bacteria but also of gram-negative bacteria. Thus, these results indicated that CE from $L b$. fermentum strain J23 contained BLS with a wide antimicrobial spectrum.
Table 4. Microbial growth parameters, derived from modified Gompertz equation, of Escherichia coli and Lactobacillus spp. ${ }^{1}$

\begin{tabular}{lccc}
\hline Item & $\mathrm{R}^{2}$ & $\mu(\mathrm{abs} / \mathrm{h})^{2}$ & $\begin{array}{c}\text { Generation } \\
\text { time }(\mathrm{h})\end{array}$ \\
\hline E. coli & 0.98 & $0.20 \pm 0.05^{\mathrm{g}}$ & $1.26 \pm 0.23^{\mathrm{a}}$ \\
$\mathrm{J} 10$ & 0.98 & $0.19 \pm 0.06^{\mathrm{g}}$ & $1.33 \pm 0.34^{\mathrm{a}}$ \\
$\mathrm{J} 20$ & 0.98 & $0.09 \pm 0.003^{\mathrm{b}}$ & $2.58 \pm 0.35^{\mathrm{f}}$ \\
$\mathrm{J} 23$ & 0.98 & $0.08 \pm 0.004^{\mathrm{a}}$ & $2.65 \pm 0.48^{\mathrm{f}}$ \\
$\mathrm{J} 25$ & 0.98 & $0.10 \pm 0.06^{\mathrm{d}}$ & $2.05 \pm 0.42^{\mathrm{cd}}$ \\
$\mathrm{J} 28$ & 0.98 & $0.08 \pm 0.005^{\mathrm{a}}$ & $2.54 \pm 0.67^{\mathrm{f}}$ \\
$\mathrm{J} 31$ & 0.99 & $0.10 \pm 0.04^{\mathrm{d}}$ & $2.37 \pm 0.31^{\mathrm{e}}$ \\
$\mathrm{J} 32$ & 0.95 & $0.10 \pm 0.07^{\mathrm{c}}$ & $1.63 \pm 0.42^{\mathrm{b}}$ \\
J33 & 0.97 & $0.11 \pm 0.08^{\mathrm{e}}$ & $1.93 \pm 0.18^{\mathrm{cd}}$ \\
$\mathrm{J} 35$ & 0.98 & $0.13 \pm 0.06^{\mathrm{f}}$ & $1.90 \pm 0.11^{\mathrm{cd}}$ \\
$\mathrm{J} 36$ & 0.97 & $0.12 \pm 0.05^{\mathrm{e}}$ & $1.36 \pm 0.14^{\mathrm{a}}$ \\
$\mathrm{J} 37$ & 0.98 & $0.09 \pm 0.006^{\mathrm{b}}$ & $2.30 \pm 0.52^{\mathrm{e}}$ \\
J38 & 0.97 & $0.12 \pm 0.06^{\mathrm{f}}$ & $1.80 \pm 0.31^{\mathrm{bc}}$ \\
\hline
\end{tabular}

${ }^{\mathrm{a}-\mathrm{g}}$ Different superscripts within a column indicate significant differences $(P<0.05)$.

${ }^{1}$ Data represent the mean values of duplicates \pm SD.

${ }^{2} \mu=$ growth rate, measured in absorbance units per hour.

\section{CONCLUSIONS}

Screening of Lactobacillus spp. isolated and identified in artisanal Mexican Cocido cheese for antimicrobial substances showed that they presented bacteriocin-like substances not only against gram-positive bacteria but also against gram-negative bacteria. This is an important finding since bacteriocins from LAB are not usually effective against gram-negative bacteria and rather present a narrow antimicrobial spectrum. Studies are undergoing to fully characterize the bacteriocin-like substances produced by $L b$. fermentum strains J20, J23, and J32 and evaluate their antimicrobial activity in dairy foods.

Table 5. Microbial growth parameters, derived from modified Gompertz equation, of Staphylococcus aureus and Lactobacillus spp. ${ }^{1}$

\begin{tabular}{lccc}
\hline Item & $\mathrm{R}^{2}$ & $\mu(\mathrm{abs} / \mathrm{h})^{2}$ & $\begin{array}{c}\text { Generation } \\
\text { time }(\mathrm{h})\end{array}$ \\
\hline Staph. aureus & 0.99 & $0.19 \pm 0.06^{\mathrm{h}}$ & $1.34 \pm 0.34^{\mathrm{a}}$ \\
$\mathrm{J} 10$ & 0.99 & $0.18 \pm 0.04^{\mathrm{h}}$ & $1.36 \pm 0.27^{\mathrm{a}}$ \\
$\mathrm{J} 20$ & 0.97 & $0.06 \pm 0.009^{\mathrm{b}}$ & $2.79 \pm 0.31^{\mathrm{g}}$ \\
$\mathrm{J} 23$ & 0.98 & $0.05 \pm 0.002^{\mathrm{a}}$ & $4.18 \pm 0.45^{\mathrm{h}}$ \\
$\mathrm{J} 25$ & 0.99 & $0.17 \pm 0.08^{\mathrm{g}}$ & $1.35 \pm 0.31^{\mathrm{a}}$ \\
$\mathrm{J} 28$ & 0.98 & $0.08 \pm 0.004^{\mathrm{c}}$ & $1.79 \pm 0.56^{\mathrm{c}}$ \\
$\mathrm{J} 31$ & 0.97 & $0.12 \pm 0.05^{\mathrm{d}}$ & $2.08 \pm 0.36^{\mathrm{d}}$ \\
$\mathrm{J} 32$ & 0.96 & $0.08 \pm 0.06^{\mathrm{c}}$ & $2.63 \pm 0.54^{\mathrm{f}}$ \\
J33 & 0.96 & $0.17 \pm 0.09^{\mathrm{f}}$ & $2.55 \pm 0.29^{\mathrm{e}}$ \\
J35 & 0.97 & $0.16 \pm 0.05^{\mathrm{e}}$ & $2.79 \pm 0.43^{\mathrm{g}}$ \\
$\mathrm{J} 36$ & 0.97 & $0.18 \pm 0.04^{\mathrm{h}}$ & $1.42 \pm 0.11^{\mathrm{b}}$ \\
J37 & 0.98 & $0.09 \pm 0.009^{\mathrm{d}}$ & $2.42 \pm 0.22^{\mathrm{e}}$ \\
J38 & 0.96 & $0.16 \pm 0.07^{\mathrm{e}}$ & $1.36 \pm 0.38^{\mathrm{a}}$ \\
\hline
\end{tabular}

${ }^{\mathrm{a}-\mathrm{h}}$ Different superscripts within a column indicate significant difference $(P<0.05)$.

${ }^{1}$ Data represent the mean value of duplicates \pm SD.

${ }^{2} \mu=$ growth rate, measured in absorbance units per hour. 

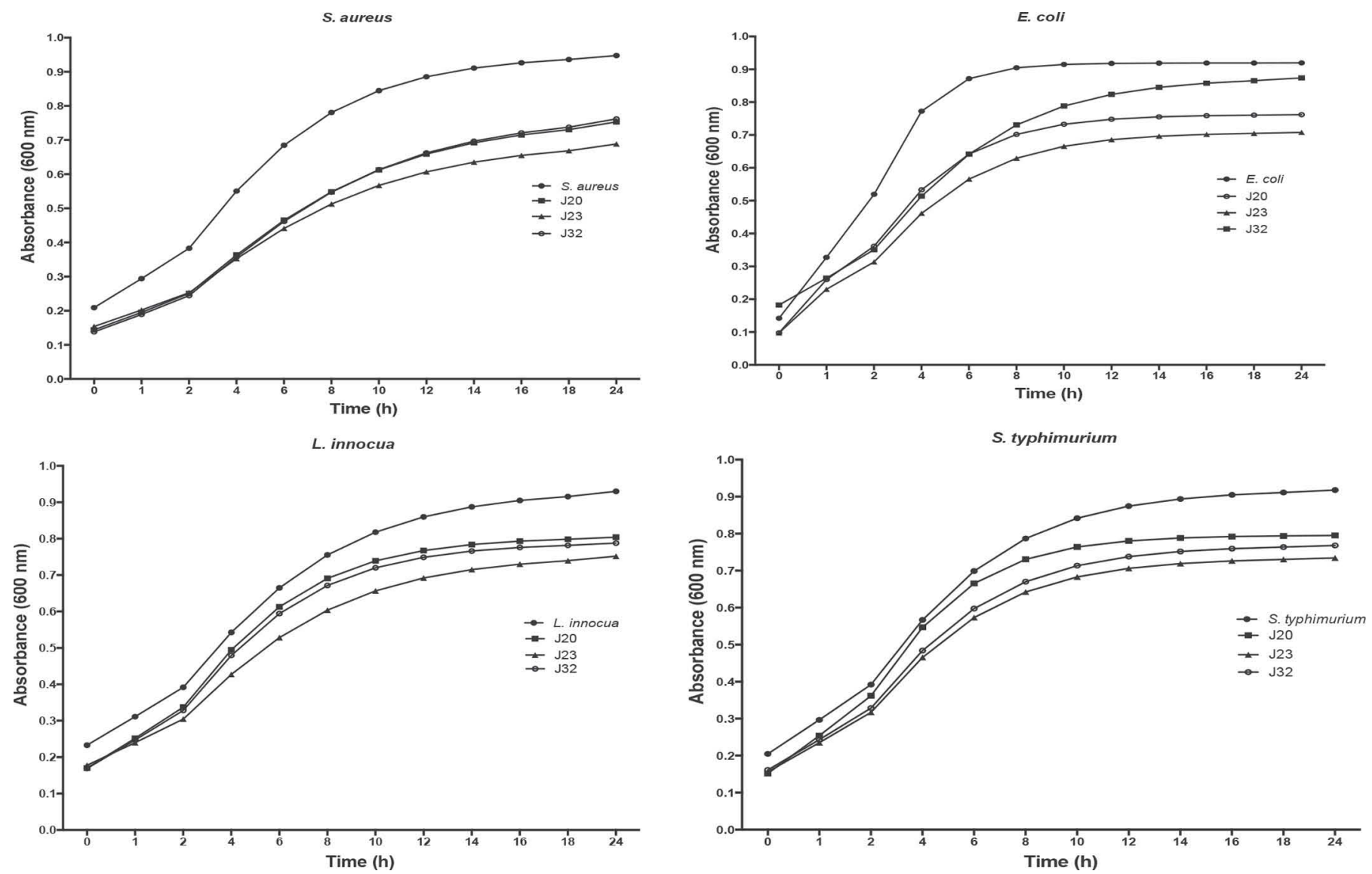

Figure 2. Growth inhibition of indicator microorganisms by crude extracts from different Lactobacillus strains. Parameters were derived from modified Gompertz equation.

Table 6. Microbial growth parameters, derived from modified Gompertz equation, of Listeria innocua and Lactobacillus spp. ${ }^{1}$

\begin{tabular}{lccc}
\hline Item & $\mathrm{R}^{2}$ & $\mu(\mathrm{abs} / \mathrm{h})^{2}$ & $\begin{array}{c}\text { Generation } \\
\text { time }(\mathrm{h})\end{array}$ \\
\hline L. innocua & 0.99 & $0.19 \pm 0.05^{\mathrm{g}}$ & $1.25 \pm 0.22^{\mathrm{a}}$ \\
J10 & 0.96 & $0.18 \pm 0.06^{\mathrm{f}}$ & $1.63 \pm 0.19^{\mathrm{b}}$ \\
J20 & 0.97 & $0.09 \pm 0.006^{\mathrm{b}}$ & $2.00 \pm 0.24^{\mathrm{d}}$ \\
J23 & 0.98 & $0.09 \pm 0.005^{\mathrm{a}}$ & $2.15 \pm 0.37^{\mathrm{e}}$ \\
J25 & 0.99 & $0.18 \pm 0.06^{\mathrm{f}}$ & $2.02 \pm 0.34^{\mathrm{d}}$ \\
J28 & 0.98 & $0.10 \pm 0.008^{\mathrm{c}}$ & $2.16 \pm 0.28^{\mathrm{e}}$ \\
J31 & 0.99 & $0.12 \pm 0.09^{\mathrm{e}}$ & $1.72 \pm 0.18^{\mathrm{c}}$ \\
J32 & 0.96 & $0.10 \pm 0.06^{\mathrm{c}}$ & $2.16 \pm 0.36^{\mathrm{e}}$ \\
J33 & 0.97 & $0.19 \pm 0.06^{\mathrm{g}}$ & $1.2 \pm 0.11^{\mathrm{a}}$ \\
J35 & 0.98 & $0.11 \pm 0.07^{\mathrm{d}}$ & $1.63 \pm 0.19^{\mathrm{b}}$ \\
J36 & 0.99 & $0.19 \pm 0.09^{\mathrm{g}}$ & $1.63 \pm 0.25^{\mathrm{b}}$ \\
J37 & 0.98 & $0.09 \pm 0.008^{\mathrm{a}}$ & $1.78 \pm 0.42^{\mathrm{c}}$ \\
J38 & 0.99 & $0.18 \pm 0.09^{\mathrm{f}}$ & $1.26 \pm 0.37^{\mathrm{a}}$ \\
\hline
\end{tabular}

${ }^{\mathrm{a}-\mathrm{g}}$ Different superscripts within a column indicate significant difference $(P<0.05)$.

${ }^{1}$ Data represent the mean value of duplicate $\pm \mathrm{SD}$.

${ }^{2} \mu=$ growth rate, measured in absorbance units per hour.
Table 7. Microbial growth parameters, derived from modified Gompertz equation, of Salmonella typhimurium and Lactobacillus spp.

\begin{tabular}{lccc}
\hline Item & $\mathrm{R}^{2}$ & $\mu(\mathrm{abs} / \mathrm{h})^{2}$ & $\begin{array}{c}\text { Generation } \\
\text { time }(\mathrm{h})\end{array}$ \\
\hline S. typhimurium & 0.99 & $0.20 \pm 0.06^{\mathrm{f}}$ & $1.25 \pm 0.15^{\mathrm{a}}$ \\
J10 & 0.97 & $0.15 \pm 0.06^{\mathrm{e}}$ & $1.6 \pm 0.15^{\mathrm{c}}$ \\
$\mathrm{J} 20$ & 0.99 & $0.09 \pm 0.003^{\mathrm{c}}$ & $2.00 \pm 0.28^{\mathrm{d}}$ \\
$\mathrm{J} 23$ & 0.99 & $0.054 \pm 0.003^{\mathrm{a}}$ & $2.76 \pm 0.18^{\mathrm{f}}$ \\
J25 & 0.98 & $0.19 \pm 0.04^{\mathrm{f}}$ & $1.26 \pm 0.11^{\mathrm{a}}$ \\
J28 & 0.99 & $0.09 \pm 0.004^{\mathrm{b}}$ & $2.60 \pm 0.22^{\mathrm{e}}$ \\
J31 & 0.96 & $0.14 \pm 0.07^{\mathrm{d}}$ & $1.59 \pm 0.12^{\mathrm{b}}$ \\
$\mathrm{J} 32$ & 0.99 & $0.08 \pm 0.004^{\mathrm{b}}$ & $2.69 \pm 0.17^{\mathrm{f}}$ \\
J33 & 0.99 & $0.14 \pm 0.04^{\mathrm{d}}$ & $1.59 \pm 0.36^{\mathrm{b}}$ \\
J35 & 0.98 & $0.15 \pm 0.07^{\mathrm{e}}$ & $1.62 \pm 0.35^{\mathrm{c}}$ \\
J36 & 0.96 & $0.19 \pm 0.05^{\mathrm{f}}$ & $1.26 \pm 0.18^{\mathrm{a}}$ \\
J37 & 0.99 & $0.09 \pm 0.003^{\mathrm{c}}$ & $2.52 \pm 0.19^{\mathrm{e}}$ \\
J38 & 0.97 & $0.15 \pm 0.09^{\mathrm{e}}$ & $1.26 \pm 0.25^{\mathrm{a}}$ \\
\hline
\end{tabular}

$\overline{\mathrm{a}}{ }^{\mathrm{f}}$ Different superscripts within a column indicate a significant difference $(P<0.05)$.

${ }^{1}$ Data represent the mean values of duplicates \pm SD.

${ }^{2} \mu=$ growth rate, measured in absorbance units per hour. 


\section{ACKNOWLEDGMENTS}

The authors thank the National Council for Science and Technology (CONACYT) of Mexico for graduate scholarships to P. Y. Heredia-Castro and J. I. MéndezRomero. The study was supported by SAGARPACONACYT Project 2010-144591. The technical assistance of María del Carmen Estrada-Montoya and Ricard Reyes-Díaz is gratefully acknowledged.

\section{REFERENCES}

Arqués, J., E. Rodríguez, M. Nuñez, and M. Medina. 2011. Combined effect of reuterin and lactic acid bacteria bacteriocins on the inactivation of food borne pathogens in milk. Food Contr. 22:457-461.

Balciunas, E. M., F. A. C. Martinez, S. D. Todorov, B. D. G. de Melo Franco, A. Converti, and R. P. de Souza Oliveira. 2013. Novel biotechnological applications of bacteriocins: A review. Food Contr. $32: 134-142$.

Basurto-Cadena, M. G. L., M. Vázquez-Arista, J. García-Jiménez, R. Salcedo-Hernández, D. K. Bideshi, and J. E. Barboza-Corona. 2012. Isolation of a new Mexican strain of Bacillus subtilis with antifungal and antibacterial activities. Scientific World J. http:// dx.doi.org/10.1100/2012/384978.

Biscola, V., S. D. Todorov, V. S. C. Capuano, H. Abriouel, A. Galvez, and B. D. G. M. Franco. 2013. Isolation and characterization of a nisin-like bacteriocin produced by a Lactococcus lactis strain isolated from charqui, a Brazilian fermented, salted and dried meat product. Meat Sci. 93:607-613.

Chowdhury, B. R., R. Chakraborty, and U. R. Chaudhuri. 2007. Validity of modified Gompertz and Logistic models in predicting cell growth of Pediococcus acidilactici $\mathrm{H}$ during the production of bacteriocin pediocin AcH. J. Food Eng. 80:1171-1175.

De Vuyst, L., R. Callewaert, and K. Crabbé. 1996. Primary metabolite kinetics of bacteriocin biosynthesis by Lactobacillus amylovorus and evidence for stimulation of bacteriocin production under unfavourable growth conditions. Microbiology 142:817-827.

Gálvez, A., H. Abriouel, R. L. López, and N. B. Omar. 2007. Bacteriocin-based strategies for food biopreservation. Int. J. Food Microbiol. 120:51-70.

Gálvez, A., R. López, H. Abriouel, and N. B. Omar. 2008. Application of bacteriocins in the control of foodborne pathogenic and spoilage bacteria. Crit. Rev. Biotechnol. 28:125-152.

Gao, Y., D. Li, and X. Liu. 2013. Evaluation of the factors affecting the activity of sakacin $\mathrm{C} 2$ against E. coli in milk. Food Contr. 30:453-458.

García, P., L. Rodríguez, A. Rodríguez, and B. Martínez. 2010. Food preservation: promising strategies using bacteriocins, bacteriophages and endolysins. Trends Food Sci. Tech. 21:373-382.

Ghanbari, M., M. Jami, W. Kneifel, and K. J. Domig. 2013. Antimicrobial activity and partial characterization of bacteriocins produced by lactobacilli isolated from Sturgeon fish. Food Contr. 32:379-385.

González, L., H. Sandoval, N. Sacristán, J. M. Castro, J. M. Fresno, and M. E. Tornadijo. 2007. Identification of lactic acid bacteria isolated from Genestoso cheese throughout ripening and study of their antimicrobial activity. Food Contr. 18:716-722.

Hartmann, H. A., T. Wilke, and R. Erdmann. 2011. Efficacy of bacteriocin-containing cell-free culture supernatants from lactic acid bacteria to control Listeria monocytogenes in food. Int. J. Food Microbiol. 146:192-199.
Karapetyan, K., N. Huseynova, R. Arutjunyan, F. Tkhruni, and T. Haertle. 2010. Perspective of using new strains of lactic acid bacteria for biopreservation. Biotechnol. Biotechnol. Equip. 24:460-464.

McClerren, A. L., L. E. Cooper, C. Quan, P. M. Thomas, N. L. Kelleher, and W. A. van der Donk. 2006. Discovery and in vitro biosynthesis of haloduracin, a two-component lantibiotic. Proc. Natl. Acad. Sci. USA 103:17243-17248.

Mezaini, A., N. E. Chihib, A. Dilmi Bouras, N. Nedjar-Arroume, and J. P. Hornez. 2009. Antibacterial activity of some lactic acid bacteria isolated from an Algerian dairy product. J. Environ. Public Health 2009:678495.

Nespolo, C. R., and A. Brandelli. 2010. Production of bacteriocinlike substances by lactic acid bacteria isolated from regional ovine cheese. Braz. J. Microbiol. 41:1009-1018.

Parada, J. L., C. R. Caron, A. B. P. Medeiros, and C. R. Soccol. 2007. Bacteriocins from lactic acid bacteria: Purification, properties and use as biopreservatives. Braz. Arch. Biol. Tech. 50:512-542.

Pinto, A. L., M. Fernandes, C. Pinto, H. Albano, F. Castilho, P. Teixeira, and P. A. Gibbs. 2009. Characterization of anti-Listeria bacteriocins isolated from shellfish: Potential antimicrobials to control non-fermented seafood. Int. J. Food Microbiol. 129:50-58.

Pinto, M. S., A. F. de Carvalho, A. C. dos Santos Pires, A. A. C. Souza, P. H. F. da Silva, D. Sobral, and A. de Lima Santos. 2011. The effects of nisin on Staphylococcus aureus count and the physicochemical properties of Traditional Minas Serro cheese. Int. Dairy J. 21:90-96.

Ponce, A. G., M. R. Moreira, C. E. Del Valle, and S. I. Roura. 2008. Preliminary characterization of bacteriocin-like substances from lactic acid bacteria isolated from organic leafy vegetables. LWT Food Sci. Technol. (Campinas.) 41:432-441.

Pringsulaka, O., N. Thongngam, N. Suwannasai, W. Atthakor, K. Pothivejkul, and A. Rangsiruj. 2012. Partial characterisation of bacteriocins produced by lactic acid bacteria isolated from Thai fermented meat and fish products. Food Contr. 23:547-551.

Reis, J. A., A. T. Paula, S. N. Casarotti, and A. L. B. Penna. 2012. Lactic acid bacteria antimicrobial compounds: Characteristics and applications. Food Eng. Rev. 4:124-140.

Seo, S. H., M. Jung, and W. J. Kim. 2014. Antilisterial and amylasesensitive bacteriocin producing Enterococcus faecium SH01 from Mukeunji, a Korean over-ripened kimchi. Food Sci. Biotechnol. 23:1177-1184.

Simova, E. D., D. B. Beshkova, and Z. P. Dimitrov. 2009. Characterization and antimicrobial spectrum of bacteriocins produced by lactic acid bacteria isolated from traditional Bulgarian dairy products. J. Appl. Microbiol. 106:692-701.

Stoyanova, L. G., E. A. Ustyugova, and A. I. Netrusov. 2012. Antibacterial metabolites of lactic acid bacteria: Their diversity and properties. Appl. Biochem. Microbiol. 48:229-243.

Todorov, S. D., and L. M. T. Dicks. 2006. Screening for bacteriocin-producing lactic acid bacteria from boza, a traditional cereal beverage from Bulgaria: Comparison of the bacteriocins. Process Biochem. 41:1-19.

Todorov, S. D., H. Prévost, M. Lebois, X. Dousset, J. G. LeBlanc, and B. D. Franco. 2011. Bacteriocinogenic Lactobacillus plantarum ST16Pa isolated from papaya (Carica papaya) - from isolation to application: Characterization of a bacteriocin. Food Res. Int. 44:1351-1363.

Todorov, S. D., M. Wachsman, E. Tomé, X. Dousset, M. T. Destro, L. M. T. Dicks, and D. Drider. 2010. Characterization of an antiviral pediocin-like bacteriocin produced by Enterococcus faecium. Food Microbiol. 27:869-879.

Torres-Llanez, M. J., B. Vallejo-Cordoba, M. E. Díaz-Cinco, M. A. Mazorra-Manzano, and A. F. González-Córdova. 2006. Characterization of the natural microflora of artisanal Mexican Fresco cheese. Food Contr. 17:683-690. 